\title{
Biodegradation of malathion by Acinetobacter johnsonii MA19 and optimization of cometabolism substrates
}

\author{
XIE Shan ${ }^{1}$, LIU Junxin ${ }^{1, *}$, LI Lin ${ }^{1}$, QIAO Chuanling ${ }^{2}$ \\ 1. Research Center for Eco-Environmental Sciences, Chinese Academy of Sciences, Beijing 100085, China. E-mail: xieshan1980@yahoo.com.cn \\ 2. Institute of Zoology, Chinese Academy of Sciences, Beijing 100080, China
}

Received 03 March 2008; revised 03 April 2008; accepted 15 April 2008

\begin{abstract}
To enhance the removal efficiency of malathion in the wastewater from organophosphate pesticide mill, a bacterium, Acinetobacter johnsonii MA19, that could degrade malathion with cometabolism was isolated from malathion-polluted soil samples using enrichment culture techniques. Four kinds of additional compounds, sodium succinate, sodium acetate, glucose, and fructose were tested to choose a favorite carbon source for the cometabolism of strain MA19. The results showed that sodium succinate and sodium acetate could promote malathion biodegradation and cell growth. The investigation results of the effects of sodium succinate concentrations on the malathion biodegradation indicated that the more sodium succinate supplied resulted in quick degradation of malathion and fast cells multiplied. Zero-order kinetic model was appropriate to describe the malathion biodegradation when the concentration of sodium succinate was more than $0.5144 \mathrm{~g} / \mathrm{L}$. The degradation rate constant $(K)$ reached the maximum value of $3.5837 \mathrm{mg} /(\mathrm{L} \cdot \mathrm{h})$ when the mass ratio of sodium succinate to malathion was $128.6 \mathrm{mg} / \mathrm{mg}$. The aquatic toxicity of the malathion was evaluated using the test organism, Limnodrilus hoffmeisteri. The data obtained suggested that the toxicity of malathion could be ignored after 84 $\mathrm{h}$ biodegradation. Our result demonstrates the potential for using bacterium A. johnsonii MA19 for malathion biodegradation and environmental bioremediation when some suitable conventional carbon sources are supplied.
\end{abstract}

Key words: bacterium Acinetobacter johnsonii; cometabolism; wastewater; malathion; toxicity

\section{Introduction}

The organophosphate pesticide malathion (O,Odimethyl-S-[1,2-di(ethoxyl-carbonyl) ethyl] phosphorodithioate) is one of the most widely used chemicals to control insects on field crops, fruits and vegetables (Chambers, 1992; Barlas, 1996). It is a neurotoxin; its high-level exposure may cause delayed cholinergic toxicity and neurotoxicity (Tuovinen et al., 1994). Malathion may disturb the central nervous system of invertebrates, affect the immune system of higher vertebrate wildlife, and hurt the adrenal glands of fish (Senanayake and Karalliedde, 1987; Galloway and Handy, 2003). The malathion wastewater discharged from pesticide factories is poisonous. It would kill aquatic organisms and threaten public health if it were discharged without proper disposal.

The methods for treating malathion wastewater include physical, chemical, and biological methods. Among these methods, the biological method is widely used for its merits of low investment, low operational costs, and environmental friendliness. Some publications have been reported on the malathion biodegradation under aerobic conditions (Bourquin, 1977; Subramanian et al., 1994).

\footnotetext{
* Corresponding author. E-mail: jxliu@ rcees.ac.cn
}

Several strains that can utilize malathion as sole phosphorus source or carbon source were successfully isolated from soil and sludge samples (Barik et al., 1984; Rosenberg and Alexander, 1979). Besides microorganisms, some enzymes, such as Fusarium oxysporum f. sp. pisi cutinase and glutathione reductase were verified to degrade malathion with high efficiency (Kim et al., 2005; Yoshii et al., 2000).

Cometabolism has recently emerged as an important technique for the biotreatment of recalcitrant compounds. Girbal et al. (2000) reported that demeton-s-methyl, an organophosphate pesticide, could be degraded with cometabolism by Corynebacterium glutamicum in the presence of fructose. The growth substrate has two effects on cometabolic process: first, it may simulate cell growth and enhance the transformation of the nongrowth substrate (Grant and Betts, 2004); second, it may act as a cosubstrate in xenobiotic metabolism by inducing certain enzymatic pathways that both the growth substrate and the nongrowth substrate may share (Aziz et al., 1999; Girbal et al., 2000). It has been verified by Barik et al. (1984) and Bourquin (1977) that malathion was degraded more rapidly in the environment when certain growth substrates were provided. However, there were only few reports that described malathion degradation with cometabolism, and 
its cometabolic mechanism was not clear.

The freshwater euryhaline oligochaete Limnodrilus hoffmeisteri is often associated with aquatic systems rich in organic matter. It is a common and abundant component of the estuarine communities in both oligohaline and $\beta$ mesohaline zones (up to $10 \%$ salinity) of estuaries of China (Wei and Liu, 2006). L. hoffmeisteri is sensitive to many kinds of chemical contaminants, such as insecticides (Dad et al., 1982; Timothy et al., 1988), PAH (Peter et al., 1982), and heavy metals (Laura et al., 2001). It is considered as a test organism for assessing bioaccumulation or toxicity of chemical contaminants (Laura et al., 2001; Viguri et al., 2007).

In this article, a bacterium that could degrade malathion with cometabolism was isolated from malathion-polluted soils using enrichment culture techniques. The effect of additional growth substrates on malathion degrading activity was investigated and the kinetics of biodegradation was studied. In addition, the potential toxicity during the malathion degradation process was evaluated using the test organism L. hoffmeisteri.

\section{Materials and methods}

\subsection{Chemicals and the test wastewater}

Malathion, (purity 99.5\%, from Anpel Scientific Instrument Co. Shanghai, China), was dissolved in methanol at a concentration of $20 \mathrm{~g} / \mathrm{L}$. Ethyl acetate used in the extraction and gas chromatography analysis was HPLC grade and was purchased from Sigma-Aldrich. The test wastewater was composed of malathion, carbon sources at appropriate concentrations and basal salt medium (BSM) containing: $1.0 \mathrm{~g}\left(\mathrm{NH}_{4}\right)_{2} \mathrm{SO}_{4}, 0.2 \mathrm{~g} \mathrm{KCl}, 0.2 \mathrm{~g}$ $\mathrm{MgSO}_{4} \cdot 7 \mathrm{H}_{2} \mathrm{O}, 0.04 \mathrm{~g} \mathrm{CaCl}_{2}, 0.005 \mathrm{~g} \mathrm{FeCl}_{3} \cdot 6 \mathrm{H}_{2} \mathrm{O}, 0.002$ g YE, $1.0 \mathrm{~g} \mathrm{~K}_{2} \mathrm{HPO}_{4} \cdot 3 \mathrm{H}_{2} \mathrm{O}$, and $0.2 \mathrm{~g} \mathrm{KH}_{2} \mathrm{PO}_{4}$ in 1000 $\mathrm{mL}$ distilled water. The test wastewater was sterilized by autoclaving for $15 \mathrm{~min}$ at $121^{\circ} \mathrm{C}$, the final $\mathrm{pH}$ was adjusted to 7.4, and then used for the isolation of strains and the experiment of malathion biodegradation.

\subsection{Isolation and identification of malathion-degrading bacterium}

The malathion-degrading bacteria were initially isolated from malathion-polluted soils in the suburbs of Beijing, China. In preliminary studies, we found that malathion decomposed quickly in the presence of sodium succinate. Therefore, sodium succinate was used as the co-substrate for the isolation of malathion-degrading bacteria. Enrichment of the malathion-degrading bacteria was performed by successive subculturing in the test wastewater with increasing concentration of malathion from 100 to 250 $\mathrm{mg} / \mathrm{L}$ at $30^{\circ} \mathrm{C}$ on a shaker at $160 \mathrm{r} / \mathrm{min}$. The concentration of sodium succinate in the wastewater was kept constant at $1.286 \mathrm{~g} / \mathrm{L}$. The enrichment culture of the fourth transfer was plated onto BSM agar plates containing $100 \mathrm{mg} / \mathrm{L}$ malathion and $1.286 \mathrm{~g} / \mathrm{L}$ sodium succinate. Colonies appearing on the agar plates after $2 \mathrm{~d}$ incubation at $30^{\circ} \mathrm{C}$ were picked and restreaked to ensure purity. The isolates were then inoculated into BSM containing $100 \mathrm{mg} / \mathrm{L}$ malathion and $1.286 \mathrm{~g} / \mathrm{L}$ sodium succinate for testing malathion degradation ability. An isolate, designated MA19 that is able to degrade malathion rapidly was selected for further investigation.

16S rRNA gene sequence analysis was used to identify the MA19 bacterium. Genomic DNA was prepared a standard phenolic extraction procedure. The 16S rRNA gene was amplified by PCR using the following primers: 8f (5'-AGAGTTTGATCCTGGCTTAG-3'; forward) and 1512r (5'-ACGGTTACCTTGTTACGACTT-3'; reverse). The PCR was run with following thermal profile: initial denaturation at $95^{\circ} \mathrm{C}$ for $5 \mathrm{~min} ; 30$ cycles of denaturation at $95^{\circ} \mathrm{C}$ for $1 \mathrm{~min}$, annealing at $58^{\circ} \mathrm{C}$ for $1 \mathrm{~min}$, and extension at $72^{\circ} \mathrm{C}$ for $1 \mathrm{~min}$; final extension at $72^{\circ} \mathrm{C}$ for $5 \mathrm{~min}$. The PCR products were purified and sequenced by GeneCore Biotechnology Co., Ltd., Shanghai, China. The determined sequence was compared with others in GenBank using the Clustal 1.83 software. The 16S rRNA gene sequence has been deposited in the GenBank database under accession no. DQ864703.

\subsection{Malathion biodegradation in the presence of differ- ent cometabolic substrates}

A total of $5 \mathrm{~mL}$ of cell suspension $\left(\mathrm{OD}_{600}\right.$ of the cell suspension was adjusted to 1.5) of strain MA19 was inoculated into $45 \mathrm{~mL}$ of the test wastewater. The malathion concentration was $100 \mathrm{mg} / \mathrm{L}$. Four kinds of additional carbon sources, i.e., sodium succinate $\left(\mathrm{C}_{4} \mathrm{H}_{4} \mathrm{O}_{4} \mathrm{Na}_{2} \cdot 6 \mathrm{H}_{2} \mathrm{O}\right)$, sodium acetate $\left(\mathrm{C}_{2} \mathrm{H}_{3} \mathrm{O}_{2} \mathrm{Na}\right)$, glucose $\left(\mathrm{C}_{6} \mathrm{H}_{12} \mathrm{O}_{6} \cdot \mathrm{H}_{2} \mathrm{O}\right)$, and fructose $\left(\mathrm{C}_{6} \mathrm{H}_{12} \mathrm{O}_{6}\right)$ were used to investigate the effect of carbon sources on malathion biodegradation. The concentrations of sodium succinate, sodium acetate, glucose, and fructose were $2.572,1.562,1.257$, and $1.143 \mathrm{~g} / \mathrm{L}$, respectively, to which were offered the same concentration of elemental carbon at $0.457 \mathrm{~g} / \mathrm{L}$. All the cultures were incubated at $30^{\circ} \mathrm{C}$ on a shaker at $160 \mathrm{r} / \mathrm{min}$, and regularly checked for malathion degradation and bacterial growth. The $\mathrm{pH}$ of the culture was adjusted between 7.0 and 7.5 with $1 \mathrm{~mol} / \mathrm{L} \mathrm{NaOH}$ or $1 \mathrm{~mol} / \mathrm{L} \mathrm{HCl}$ during the incubation to prevent chemical hydrolysis of malathion at alkaline $\mathrm{pH}$. Uninoculated test was completed as a control.

The degradation constant $(K, \mathrm{mg} /(\mathrm{L} \cdot \mathrm{h}))$ was calculated using zero-order kinetics equation:

$\mathrm{d} N / \mathrm{d} t=-K$

where, $N(\mathrm{mg} / \mathrm{L})$ and $t(\mathrm{~d})$ represent the residual amount of malathion and degradation time, respectively. This was performed on the basis of the data obtained during the exponential phase of degradation.

\subsection{Malathion biodegradation and the toxicity testing in the presence of sodium succinate}

Eight concentrations of sodium succinate, i.e., 0.129, $0.257,0.514,1.286,2.572,7.716,12.860$, and $25.720 \mathrm{~g} / \mathrm{L}$ were selected to investigate the effects of sodium succinate concentration on malathion biodegradation. The initial malathion concentration was $100 \mathrm{mg} / \mathrm{L}$. The degradation 
constant $(K)$ was calculated by Eq.(1) based on zero-order kinetics.

The toxicity of malathion was evaluated using the test organism L. hoffmeisteri. A standard experimental procedure was used (Flores-Tena and Martínez-Tabche, 2001). The test organism was first collected from a malathionfree site at a local reservoir and was washed several times with tap water and then with BSM. Prior to the experiment, the worms were acclimatized to laboratory conditions for $7 \mathrm{~d}$ by and were kept in a 2-L aquarium filled with BSM at $20 \pm 2{ }^{\circ} \mathrm{C}$ and $12 \mathrm{~h}$ light/12 $\mathrm{h}$ darkness. Dissolved oxygen was maintained at $60 \%$ saturation by aeration. The strain MA19 was inoculated into the test wastewater and cultured as described in Section 1.3. The concentrations of malathion and sodium succinate were $100 \mathrm{mg} / \mathrm{L}$ and $2.572 \mathrm{~g} / \mathrm{L}$, respectively in the test wastewater. During the degradation process, a total of $1 \mathrm{~mL}$ sample was withdrawn from the flask every $12 \mathrm{~h}$ and the residual malathion was determined using GC analysis. A 10-mL sample was transferred to a 50-mL bottle and diluted to $20 \mathrm{~mL}$ with $\mathrm{BSM}$, then incubated with 10 pieces of L. hoffmeisteri worms. The temperature and lighting conditions were maintained as described above. The mortality rate of the test organism was determined after incubation for 24, 48, and $72 \mathrm{~h}$. Worms were considered to be dead when there was no response to pressing with a blunt glass rod. Dead specimens were removed after detection. The wastewater without malathion was inoculated with strain MA19 as described in Section 1.3, and then incubated with 10 pieces of L. hoffmeisteri worms, which was run as a control. All data were represented as the mean value of triplicate experiments.

\subsection{Analytical methods}

Cell density was monitored by measuring $\mathrm{OD}_{600}$ using a spectrophotometer (DR5000, Hach, USA). Malathion was extracted with ethyl acetate for $10 \mathrm{~min}$, and its concentration was determined by gas chromatography with a nitrogen phosphorus detector (GC-NPD, Agilent, USA). An HP-5 capillary column $(30.0 \mathrm{~m} \times 320 \mu \mathrm{m} \times 0.25$ $\mu \mathrm{m})$ was used. Nitrogen gas was used as the carrier gas at a flow of $1 \mathrm{~mL} / \mathrm{min}$. The temperature of injection and detector was 240 and $250^{\circ} \mathrm{C}$, respectively; the oven temperature was programmed to increase from 120 to $200^{\circ} \mathrm{C}$ at $20^{\circ} \mathrm{C} / \mathrm{min}$, to $220^{\circ} \mathrm{C}$ at $2^{\circ} \mathrm{C} / \mathrm{min}$, and to $240^{\circ} \mathrm{C}$ (for 3 $\min$ ) at $20^{\circ} \mathrm{C} / \mathrm{min}$. The retention time of malathion was 12.412 min. Scanning electron microscopy (SEM) was used to examine the cells. The microbial samples were fixed with osmium tetroxide and then dehydrated in an ethanol solution (Mulchandani et al., 1999). The goldcoated samples were viewed in a Quanta 200 scanning electron microscope (FEI, USA).

\section{Results and discussion}

\subsection{Isolation and identification of the malathion- degrading microorganism}

After 4 times of enrichment processes, twenty different isolates were obtained from malathion-polluted soils. One of them, named strain MA19 that showed the highest malathion-degrading capability, was selected for further study. The strain was Gram-negative and oxidase-negative. SEM observation showed that strain MA19 was a coccobacillus with no budding and no flagella (Fig. 1). The 16S rRNA gene sequence of strain MA19 was very similar to that of Acinetobacter johnsonii strains $(99.4 \%$ homology), thus the strain MA19 was affiliated to Acinetobacter sp.

\subsection{Malathion biodegradation in the presence of differ- ent cometabolic substrates}

The strain MA19 could not utilize malathion as the sole carbon source and energy source (Fig. 2), but it could degrade malathion in the presence of sodium succinate. This phenomenon suggested that $A$. johnsonii MA19 could decompose malathion with cometabolism. Four kinds of additional carbon sources, i.e., sodium succinate, sodium acetate, glucose, and fructose were tested to choose a favorite carbon source for malathion cometabolism of strain MA19. Figure 3 shows the malathion concentrations and cell growth during A. johnsonii MA19 biodegradation when the carbon sources were added as growth substrates. Results showed that sodium succinate and

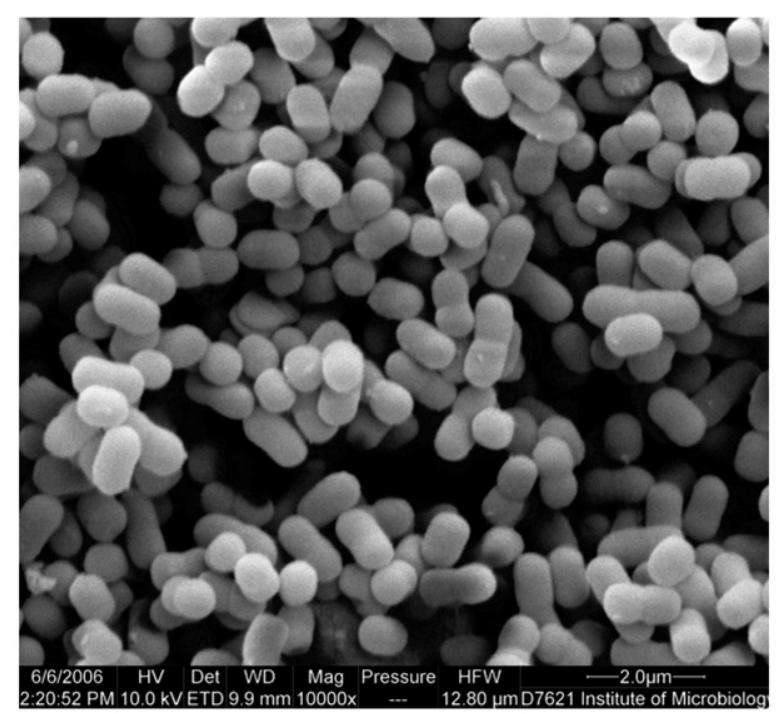

Fig. 1 Scanning electron micrograph of strain MA19.

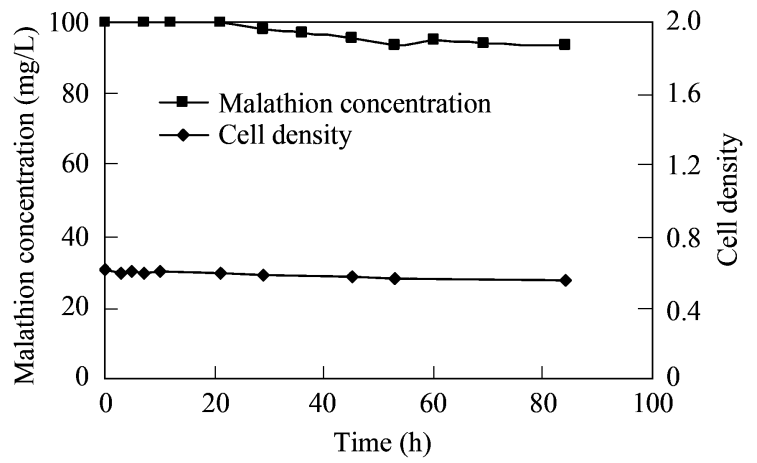

Fig. 2 Malathion degradation and cell density of MA19 in the test wastewater with malathion as sole carbon source. 

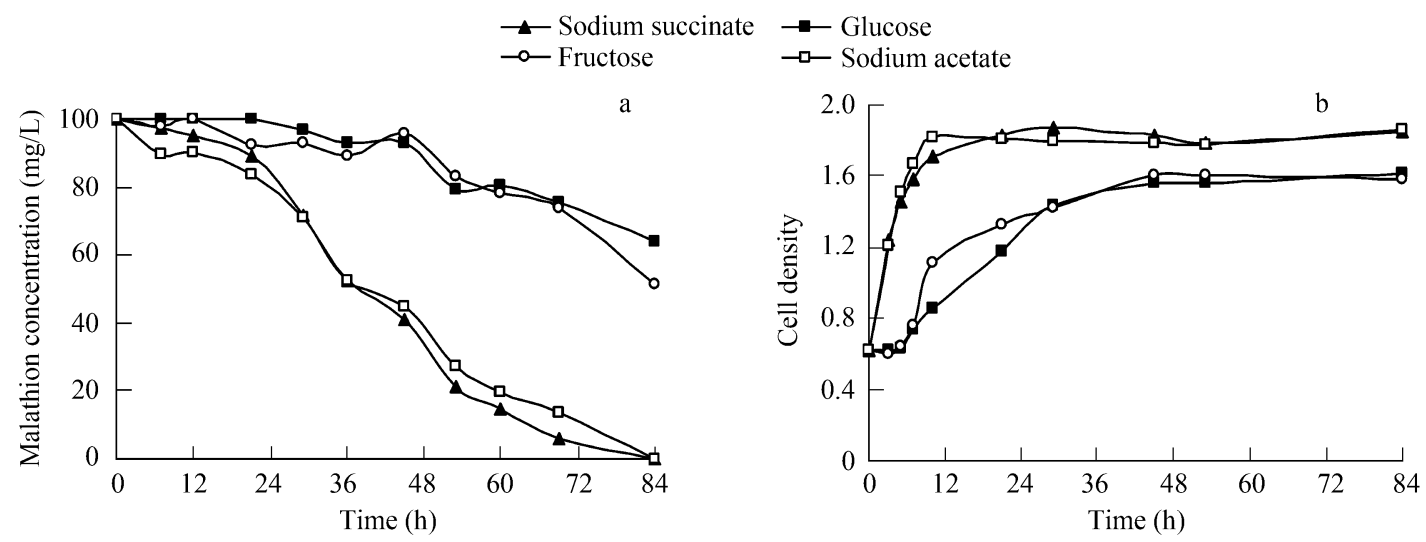

Fig. 3 Malathion degradation (a) and cell density (b) of MA19 in the test wastewater with different kinds of additional carbon sources.

sodium acetate greatly accelerated the degradation of malathion, whereas glucose and fructose had little effect on malathion biodegradation. Almost $100 \%$ of malathion was decomposed in the presence of sodium acetate or sodium succinate in $84 \mathrm{~h}$. In contrast, only $26 \%$ and $30 \%$ of malathion was decomposed by addition of glucose and fructose, respectively. When sodium acetate was used as co-substrate, the cell density $\left(\mathrm{OD}_{600}\right)$ increased from 0.605 to 1.813 in first $10 \mathrm{~h}$, whereas the cell density increased slowly with an addition of glucose or fructose. A zero-order kinetics model was used to determine the rate constants $(K)$ for malathion degradation in the presence of co-substrate, sodium succinate or sodium acetate. The rate constants $(K)$ were $1.4183 \mathrm{mg} /(\mathrm{L} \cdot \mathrm{h})\left(R^{2}=0.9612\right)$ and $1.2880 \mathrm{mg} /(\mathrm{L} \cdot \mathrm{h})\left(R^{2}=0.9797\right)$ in the presence of sodium succinate and sodium acetate, respectively (Fig. 4).

Compared with simple carbohydrates (i.e., glucose or fructose), the presence of short-chain fatty acids (i.e., sodium succinate or sodium acetate) could widely accelerate malathion degradation. A previous study demonstrated that Acinetobacter strains grew well on short-chain fatty acids (e.g., acetate), but showed poor growth on simple carbohydrates (e.g., glucose) (Kim et al., 1997). Therefore, the short-chain fatty acids were favorite carbon sources of Acinetobacter strains. The presence of favorite carbon sources, sodium succinate or sodium acetate accelerated cell growth, reduced the toxicity of the pesticide, and dras-

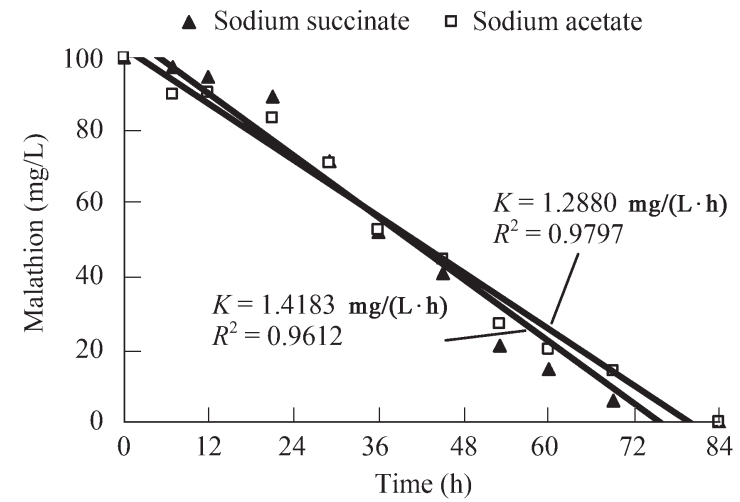

Fig. 4 Degradation constants $(K)$ for malathion based on zero-order kinetics when sodium succinate or sodium acetate was used as a cosubstrate. tically promoted the degradation of malathion, whereas glucose or fructose did not have such effect.

\subsection{Malathion biodegradation and toxicity test in the presence of sodium succinate}

Sodium succinate was used as cometabolic substrate to investigate the effect of substrate concentrations on the malathion biodegradation (Fig. 5). When sodium succinate concentration was less than $1.286 \mathrm{~g} / \mathrm{L}$, only $60 \%$ of malathion was degraded in $72 \mathrm{~h}$. In contrast, malathion degradation was much faster the concentration of sodium succinate was $7.716 \mathrm{~g} / \mathrm{L}$ or higher. The malathion was completely decomposed within $29 \mathrm{~h}$ at the concentration of $12.860 \mathrm{~g} / \mathrm{L}$. The $\mathrm{OD}_{600}$ increased from 0.58 to 1.72 in $7 \mathrm{~h}$ at $7.716 \mathrm{~g} / \mathrm{L}$ of sodium succinate, compared with an increase in the $\mathrm{OD}_{600}$ value from 0.58 to 0.85 at 0.129 $\mathrm{g} / \mathrm{L}$ of sodium succinate. Our results showed that the more sodium succinate supplied resulted in quick degradation of malathion and fast cell multiplied. It was proposed that the cometabolic transformation rate of the non-growth substrate was promoted by increasing the concentration of growth substrate because a greater population of cells was produced.

The malathion degradation results were well described by a zero-order kinetics model with a high correlation coefficient ( $R^{2}$ between 0.9527 and 0.9923 ) when the sodium succinate concentration was more than $0.514 \mathrm{~g} / \mathrm{L}$ (Fig. 6 and Table 1). Figure 7 shows the degradation rate constants $K$ for malathion at different mass ratios of

Table 1 Malathion degradation kinetics by MA19 in the test wastewater supplemented with different concentrations of sodium succinate

\begin{tabular}{lll}
\hline $\begin{array}{l}\text { Concentration of sodium } \\
\text { succinate }(\mathrm{g} / \mathrm{L})\end{array}$ & $K(\mathrm{mg} /(\mathrm{L} \cdot \mathrm{h}))$ & $R^{2}$ \\
\hline 0.129 & - & - \\
0.257 & - & - \\
0.514 & 0.6848 & 0.9674 \\
1.286 & 0.9005 & 0.9910 \\
2.572 & 1.4183 & 0.9612 \\
7.716 & 2.8984 & 0.9527 \\
12.860 & 3.5837 & 0.9923 \\
25.720 & 2.8995 & 0.9806 \\
\hline
\end{tabular}

"-": the degradation process can not be simulated by a zero-order kinetics model. 

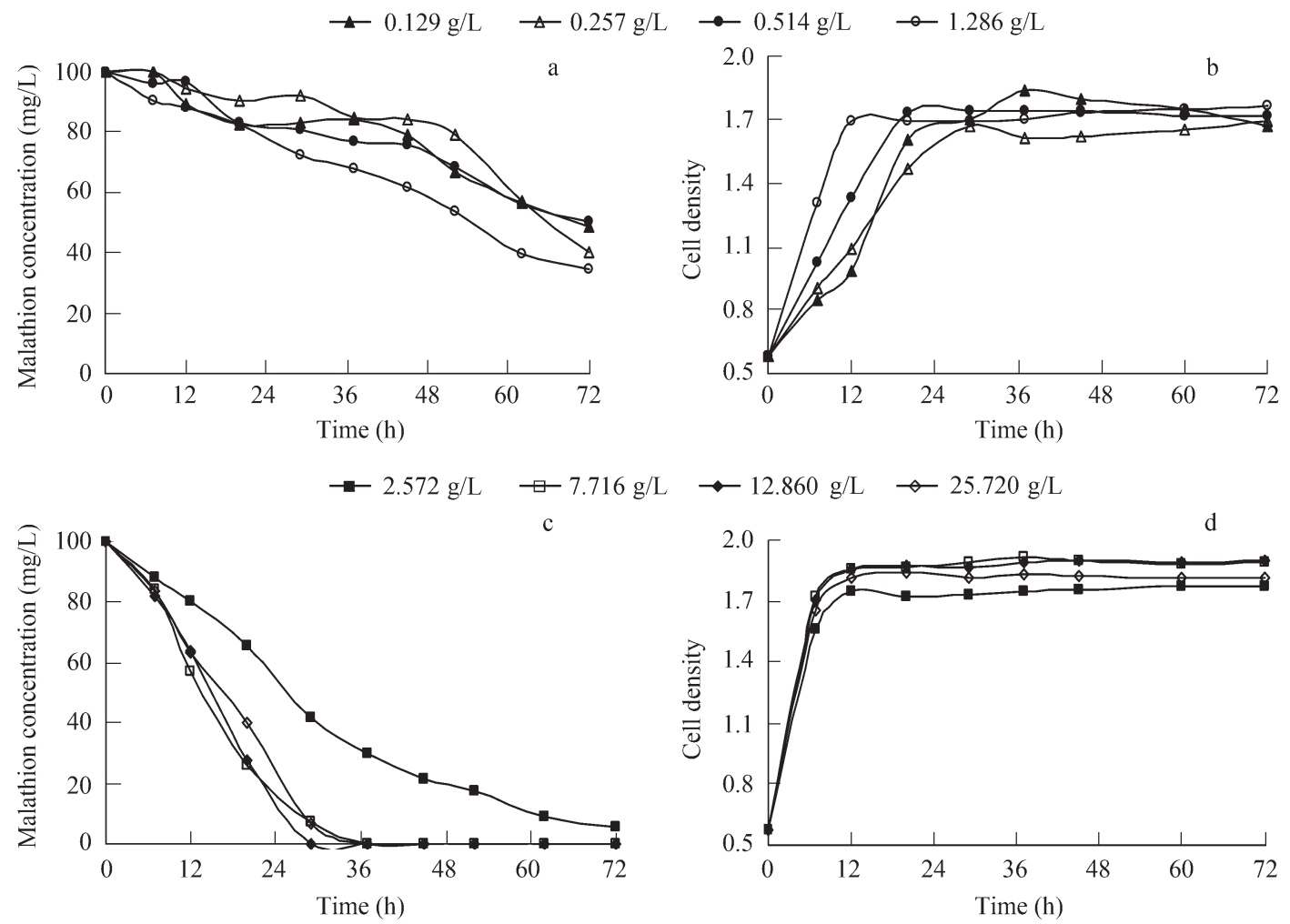

Fig. 5 Malathion degradation (a), (c) and cell growth (b), (d) in the test wastewater with different concentrations of sodium succinate.

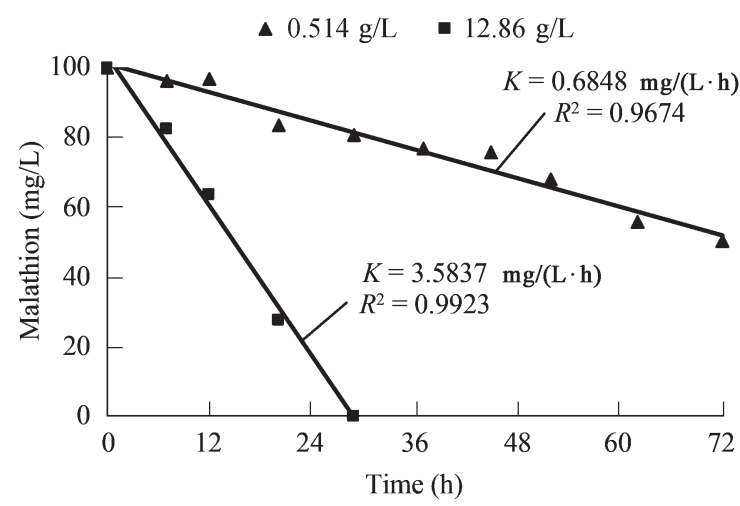

Fig. 6 Degradation constants $(K)$ for malathion based on zero-order kinetics with different concentrations of sodium succinate.

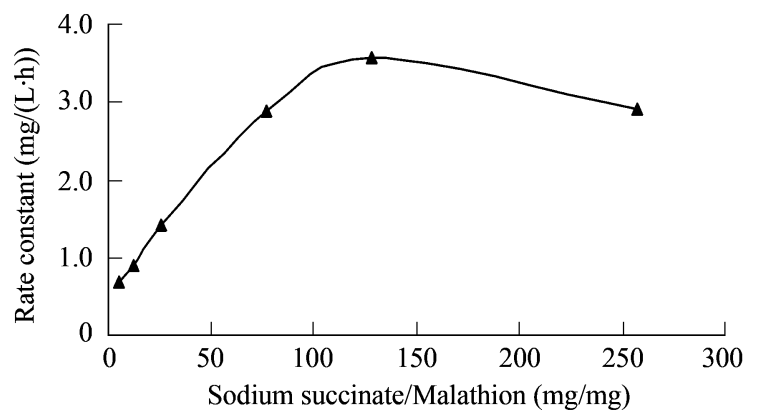

Fig. 7 Degradation rate constants $(K)$ for malathion at different mass ratios of sodium succinate to malathion.

sodium succinate to malathion. The $K$ value reached a maximum of $3.5837 \mathrm{mg} /(\mathrm{L} \cdot \mathrm{h})$ when the ratio of sodium succinate to malathion was $128.6 \mathrm{mg} / \mathrm{mg}$, then dropped to
$2.8995 \mathrm{mg} /(\mathrm{L} \cdot \mathrm{h})$ when the ratio increased from 128.6 to $257.2 \mathrm{mg} / \mathrm{mg}$. This phenomenon could be attributed to the sequential utilization of sodium succinate and malathion when the concentration of sodium succinate was high enough. Similar results were obtained by Harder et al. (1982), who pointed out that the utilization pattern of mixed substrates was dependent upon their concentrations. When the growth substrate was present in high concentration, sequential utilization of growth substrate and non-growth substrate occurred; however, when the growth substrate concentration was growth limiting, simultaneous utilization of the mixed substrates appeared to be the general response. This curve of degradation rate constants could be used to estimate the $K$ value and the degradation time when the mass ratios were known.

Malathion is a poisonous chemical that can affect the central nervous system of invertebrates by inhibiting cholinesterase enzymes, and exposure to high doses can cause fatal poisoning (Galloway and Handy, 2003). Rodriguez et al. (2006) suggested that the euryhaline oligochaete $L$. hoffmeisteri could be a suitable test organism for sediment chronic toxicity testing in freshwaterdominated sections of the estuaries, because of its easy culturing and tolerance to low and moderate salinity, up to $15 \%$ o. Therefore, the potential toxicity of the test wastewater with residual malathion was evaluated using the test organism L. hoffmeisteri. Results showed that the malathion concentration in the test wastewater decreased from 100 to $0 \mathrm{mg} / \mathrm{L}$ in $84 \mathrm{~h}$, which was accompanied by a progressive decline, from $97 \%$ to $0 \%$, in mortality of the test organism (Fig. 8). The mortality rates of $L$. hoffmeisteri in the control bottles were similar to the 


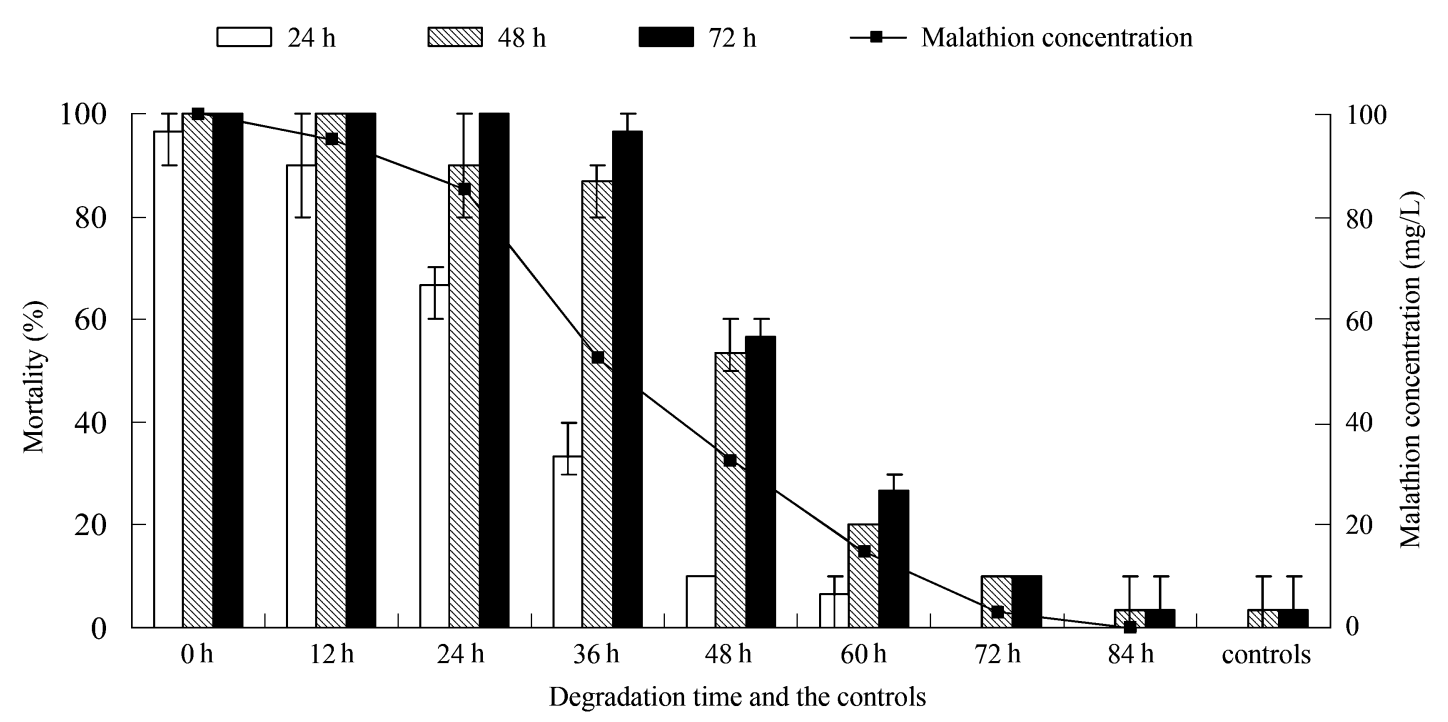

Fig. 8 Malathion concentration and mortality of $L$. hoffmeisteri during the biodegradation process after 24,48 , and $72 \mathrm{~h}$ incubation of the test organisms. All data are shown as the mean values of triplicate experiments.

mortality rates after $84 \mathrm{~h}$ of biodegradation of malathion. The results demonstrated that the potential toxicity of the test wastewater decreased dramatically during malathion biodegradation, and L. hoffmeisteri was a good candidate for pesiticide toxicity testing.

\section{Conclusions}

Acinetobacter johnsonii MA19 isolated from malathionpolluted soils could effectively degrade malathion in the wastewater with cometabolism, by the addition of sodium succinate or sodium acetate as co-substrate. Therefore, the short-chain fatty acids were more suitable than the carbohydrates as the carbon sources for cometabolism of malathion. Nearly $100 \%$ of an initial amount of malathion $(100 \mathrm{mg} / \mathrm{L})$ could be degraded in $84 \mathrm{~h}$ in the presence of $2.572 \mathrm{~g} / \mathrm{L}$ sodium succinate or $1.562 \mathrm{~g} / \mathrm{L}$ sodium acetate. The results also showed that the more sodium succinate supplied could enhance malathion degradation, and cells multiplication. The degradation of malathion accorded with a zero-order kinetics model, and the rate constant $(K)$ reached a maximum of $3.5837 \mathrm{mg} /(\mathrm{L} \cdot \mathrm{h})$ when the mass ratio of sodium succinate to malathion was $128.6 \mathrm{mg} / \mathrm{mg}$.

The potential toxicity test of $L$. hoffmeisteri showed that the mortality rates dramatically decreased with biodegradation of malathion and the potential toxicity almost disappeared after $84 \mathrm{~h}$ biodegradation.

\section{Acknowledgments}

This work was supported by the National Natural Science Foundation of China (No. 50538090) and the National Hi-Tech Research and Development Program (863) of China (No. 2005AA601020).

\section{References}

Aziz C E, Georgiou G, Speitel G E Jr, 1999. Cometabolism of chlorinated solvents and binary chlorinated solvent mix- tures using M. trichosporium OB3b PP358. Biotechnology and Bioengineering, 65(1): 100-107.

Barik S, Munnecke D M, Fletcher J S, 1984. Bacterial degradation of three dithioate pesticides. Agricultural Wastes, 10(1): 81-94.

Barlas N E, 1996. Toxicological assessement of biodegraded malathion in albino mice. Bulletin of Environmental Contamination and Toxicology, 57(5): 705-712.

Bourquin A W, 1977. Degradation of malathion by salt-marsh microorganisms. Applied and Environmental Microbiology, 33(2): 356-362.

Chambers W H, 1992. Organophosphorous compounds: an overview. In: Organophosphates, Chemistry, Fate, and Effects (Chambers J E, Levi P E, eds.). San Diego: Academic Press. 3-17.

Dad N K, Qureshi S A, Pandya V K, 1982. Acute toxicity of two insecticides to tubificid worms, Tubifex tubifex and Limnodrilus hoffmeisteri. Environment International, 7(5): 361-363.

Flores-Tena F J, Martínez-Tabche L, 2001. The effect of chromium on the hemoglobin concentration of Limnodrilus hoffmeisteri (Oligochaeta: Tubificidae). Ecotoxicology and Environmental Safety, 50(3): 196-202.

Galloway T, Handy R, 2003. Immunotoxicity of organophosphorous pesticides. Ecotoxicology, 12(1-4): 345-363.

Girbal L, Rols J L, Lindley N D, 2000. Growth rate influences reductive biodegradation of the organophosphorus pesticide demeton by Corynebacterium glutamicum. Biodegradation, 11(6): 371-376.

Grant R J, Betts W B, 2004. Mineral and carbon usage of two synthetic pyrethroid degrading bacterial isolates. Journal of Applied Microbiology, 97(3): 656-662.

Harder W, Dijkhuizen L, Postgate J R, 1982. Strategies of mixed substrate utilization in microorganisms. Philosophical Transactions of the Royal Society of London, Series B, 297(1088): 459-480.

Kim M H, Hao O J, Wang N S, 1997. Acinetobacter isolates from different activated sludge processes: characteristics and neural network identification. FEMS Microbiology Ecology, 23(3): 217-227.

Kim Y H, Ahn J Y, Moon S H, Lee J, 2005. Biodegradation and detoxification of organophosphate insecticide, malathion by 
Fusarium oxysporum f. sp. pisi cutinase. Chemosphere, 60(10): 1349-1355.

Martinez-Tabche L, DE LOS Angles Grajeday Ortega M, Ramirez Mora B, German Faz C, Lopez Lopez E, Galar Martinez M, 2001. Hemoglobin concentration and acetylcholinesterase activity of oligochaetes in relation to lead concentration in spiked sediments from Ignacio Ramirez Reservoir. Ecotoxicology and Environment Safety, 49(1): $76-83$.

Mulchandani A, Kaneva I, Chen W, 1999. Detoxification of organophosphate nerve agents by immobilized Escherichia coli with surface-expressed organophosphorus hydrolase. Biotechnology and Bioengineering, 63(2): 216-223.

Peter M C, Melody A F, Ralph O B, 1982. Relative tolerances of selected aquatic oligochaetes to individual pollutants and environmental factors. Aquatic Toxicology, 2(1): 47-67.

Rodriguez P, Arrate J, Martinez-Madrid M, Reynoldson T, Schumacher V, Viguri J, 2006. Ecotoxicity of sediments from Santander Bay to the euryhaline freshwater oligochaete Limnodrilus hoffmeisteri. Hydrobiologia, 564(1): 157-169.

Rosenberg A, Alexander M, 1979. Microbial cleavage of various organophosphorus insecticides. Applied and Environmental Microbiology, 37(5): 886-891.

Senanayake N, Karalliedde L, 1987. Neurotoxic effects of organophosphorus insecticides. New England Journal of
Medicine, 316(13): 761-763.

Subramanian G, Sekar S, Sampoornam S, 1994. Biodegradation and utilization of organophosphorus pesticides by cyanobacteria. International Biodeterioration and Biodegradation, 33(1): 129-143.

Timothy J K, David S W, Peter F L, 1988. Sublethal responses to endrin in sediment by Limnodrilus hoffmeisteri (Tubificidae), and in mixed-culture with Stylodrilus heringianus (Lumbriculidae). Aquatic Toxicology, 13(3): 227-249.

Tuovinen K, Kalistekorhone E, Raushel F M, Hänninen O, 1994. Phosphotriesterase - a promising candidate for use in detoxification of organophosphates. Fundamental and Applied Toxicology, 23(4): 578-584.

Viguri J R, Irabien M J, Yusta I, Sotoc J, Gómezc J, Rodriguezd P, Martinez-Madride M, Irabiena J A, Coza A, 2007. Physico-chemical and toxicological characterization of the historic estuarine sediments: a multidisciplinary approach. Environment International, 33(4): 436-444.

Wei Y S, Liu J X, 2006. Sludge reduction with a novel combined worm-reactor. Hydrobiologia, 564(1): 213-222.

Yoshii K, Tsumura Y, Ishimitsu S, Tonogai Y, Nakamuro K, 2000. Degradation of malathion and phenthoate by glutathione reductase in wheat germ. Journal of Agricultural and Food Chemistry, 48(6): 2502-2505. 